\title{
MIGRATION OF IRON, ALUMINIUM, CALCIUM, MAGNESIUM AND SILICON FROM CERAMIC MATERIALS INTO FOOD SIMULANT
}

\author{
Ilze Cakste*, Mara Kuka, Peteris Kuka \\ Department of Chemistry, Faculty of Food Technology, Latvia University of Agriculture, Liela iela 2, Jelgava, Latvia, \\ e-mail: ilze.cakste@llu.lv
}

\begin{abstract}
Ceramics are widely used as kitchen ware. Pottery in contact with food can be a source of various compounds from clay and glazing. The potential migration of toxic lead and cadmium from ceramic is well-known and is evaluated by the specific maximum migration levels (acceptable limits being set by the Food Contact Materials Regulation (EC) 1935/2004). Besides lead and cadmium other elements have been detected in glazed ceramic ware that could migrate during food processing. Migration experiments were performed on 10 commercially available glazed and unglazed stewing potteries (produced in Latvia and China). The migration of iron, aluminium, calcium, magnesium and silicon from the ceramics was carried out in $4 \%(\mathrm{v} / \mathrm{v})$ acetic acid water solution $\left(24,48\right.$ and $72 \mathrm{~h}$ at $20{ }^{\circ} \mathrm{C} ; 30$, 60 and $90 \mathrm{~min}$ at $180^{\circ} \mathrm{C}$ ). The concentrations of elements which had migrated into the test solutions were measured by absorption spectrometry $(\mathrm{Fe}, \mathrm{Al}$ and $\mathrm{Si}$ ) and titration (summary $\mathrm{Ca}$ and $\mathrm{Mg}$ ). The migration of iron, aluminium, calcium, magnesium and silicon was observed in all tested ceramics samples. Overall, the migration of studied elements was higher in unglazed stewing potteries and increased with temperature. Migration was decreased in repeatedly used ware.
\end{abstract}

Keywords: glazed and unglazed ceramics, migration, food contact.

\section{Introduction}

Ceramics stewing potteries are widely used as kitchen ware. As ceramics are made from natural material clay, they contain various elements which have a potential to migrate into food contained within. The potential migration of toxic lead and cadmium from ceramic glazing is well-known.

The EU Framework Regulation EC 1935/2004 determines the specific maximum migration levels (SML) into food only for cadmium and lead (Commission Directive 2005/31/EC). The migration of other elements from ceramic could be expected and was detected in many kinds of glazed ceramic ware.

Previously the migration experiments of toxic metals from ceramic food packaging materials into acid food simulants were carried out (Dong et al., 2014; Lin et al., 2014; Dong et al., 2015; Szynal et al., 2016). The effects of $\mathrm{pH}$, nature of acid and temperature on trace element migration have been described in ceramic ware treated with 18 commercially available glazes. Besides of the well-studied lead and cadmium, the migration of other toxic and non-toxic elements such as aluminium, boron, barium, cobalt, chrome, copper, iron, lithium, magnesium, manganese, nickel, antimony, tin, strontium, titanium, vanadium, zinc and zirconium was investigated in order to evaluate their potential health hazards (Bolle et al., 2012; Demont et al., 2012).

The aim of the study was to investigate the migration of iron, aluminium, calcium, magnesium and silicon into food simulants from ceramic - stewing potteries, available on the Latvian market. Potential consumer exposure can thereby be estimated from the release of these elements into food. Permissible migration limits for these elements have not yet been defined by EU laws.

\section{Materials and Methods}

Ceramics stewing potteries were obtained on the Latvian market: four glazed ware (No. 1, No. 2, No. 3, No. 4; produced in Latvia), four unglazed pottery (No. 5, No. 6, No. 7, No. 8; produced in Latvia), two glazed stewing potteries (No. 9, No. 10; produced in China). Ceramics potteries used in this study correspond to category 3 (cooking ware according to Commission Directive 2005/31/EC). Extraction levels of aluminium, iron and silicon were determined in a similar way as the extraction levels of lead and cadmium according to Commission Directive 2005/31/EC) and calculated as $\mathrm{mg}$ of element per surface area (Table 1).

Table 1

Surface area of different potteries

\begin{tabular}{cccc}
\hline \multicolumn{2}{c}{ Glazed pottery } & \multicolumn{2}{c}{ Unglazed pottery } \\
\hline No. & $\begin{array}{c}\text { Surface area, } \\
\mathbf{d m}^{\mathbf{2}}\end{array}$ & No. & $\begin{array}{c}\text { Surface area, } \\
\mathbf{d m}^{\mathbf{2}}\end{array}$ \\
\hline 1 & 2.63 & 5 & 5.65 \\
2 & 2.55 & 6 & 2.32 \\
3 & 1.45 & 7 & 1.67 \\
4 & 2.92 & 8 & 1.86 \\
9 & 1.37 & & \\
10 & 2.77 & & \\
\hline
\end{tabular}

Preparation of the sample

The samples were cleaned from grease or other matter likely to affect the test. The samples were washed in a solution containing a household liquid detergent at a temperature of approximately $40{ }^{\circ} \mathrm{C}$, rinsing first in tapwater and then in distilled water, drained and dried so as to avoid any stain (Commission Directive 2005/31/EC).

\section{Reagents}

All the reagents were of analytical quality.

$4 \%$ (v / v) acetic acid in aqueous solution was prepared as follows: $40 \mathrm{~mL}$ of glacial acetic acid were added to water, and then water was added until the final volume of $1000 \mathrm{~mL}$.

Experiments were carried out

The migration of iron, aluminium, calcium, magnesium and silicon from the ceramics was carried out in $4 \%(\mathrm{v} / \mathrm{v})$ acetic acid water solution (24, 48 and $72 \mathrm{~h}$ at 
$20 \pm 2{ }^{\circ} \mathrm{C} ; 30,60$ and $90 \mathrm{~min}$ at $180 \pm 5{ }^{\circ} \mathrm{C}$ ). 3 samples were taken from each ware and used for analysis.

Determination of content of iron, aluminium and silicon Concentration of iron, aluminium and silicon were determined by microprocessor photometer MPM 3000 from WTW and commercially available reagent kits from MERCK according to manufacturer's protocol. The concentration of iron was determined according to MERCK method No. 14761/2. The concentration of aluminium was determined according to MERCK method No. 1.14825.0001. The concentration of silicon was determined according to MERCK method No. 1.14794.0001.

Determination of content of calcium and magnesium The calcium and magnesium concentration was determined using titration with a standardized solution of ethylenediaminetetra acetic acid (EDTA) disodium salt (Pastare et al., 2007).

\section{Statistical analysis}

All presented data are the averages of triplicate measurements. The results are presented as the mean \pm standard deviation (SD). Data analysis was performed using in-built analysis of Microsoft Excel 2010.

\section{Results and Discussion}

Main components of clay used to make potteries are $\mathrm{Na}_{2} \mathrm{O} \cdot \mathrm{K}_{2} \mathrm{O} \cdot \mathrm{MgO} \cdot \mathrm{FeO} \cdot \mathrm{CaO} \cdot \mathrm{Al}_{2} \mathrm{O}_{3} \cdot \mathrm{SiO}_{2}$ and their migration into food is expected. The migration of different elements has been detected in various kinds of glazed ceramic ware. Meanwhile, very scarce information is available on migration of iron, aluminium, calcium, magnesium and silicon from clay ceramics. Current study was designed to study migration of elements present in clay like iron, aluminium, silicon, calcium and magnesium from glazed and unglazed stewing potteries into the acid food stimulant (4\% (v / v) acetic acid water solution) at temperatures $20 \pm 2$ and $180 \pm 5{ }^{\circ} \mathrm{C}$.

\section{Migration of iron from glazed ceramic}

Figure 1 shows the migration of iron at $20 \pm 2{ }^{\circ} \mathrm{C}$. Iron was identified in all samples tested and the amount of iron increased over time. The highest migration of iron was observed for sample No. 3. Such a difference could indicate lower quality of glazing used for sample No. 3. Increase in temperature to $180 \pm 5^{\circ} \mathrm{C}$ markedly facilitated migration of iron in all the samples (Figure 2) as migration just after 60 minutes was higher than migration at $20 \pm 2{ }^{\circ} \mathrm{C}$ for $24-72 \mathrm{~h}$ (Figure 1). Overall, similar migration tendency was observed at both temperatures tested and the highest migration at both temperatures was observed for sample No. 3, followed by samples No. 9 and No. 1 .

Migration of iron from glazed new pottery and repeatedly used pottery was compared and migration was markedly decreased after repeated use of cooking ware (Figure 3). Apparent explanation is that more readily soluble compounds are washed out over two cycles of use, and the remaining clay components are more stable against acidic food simulant.

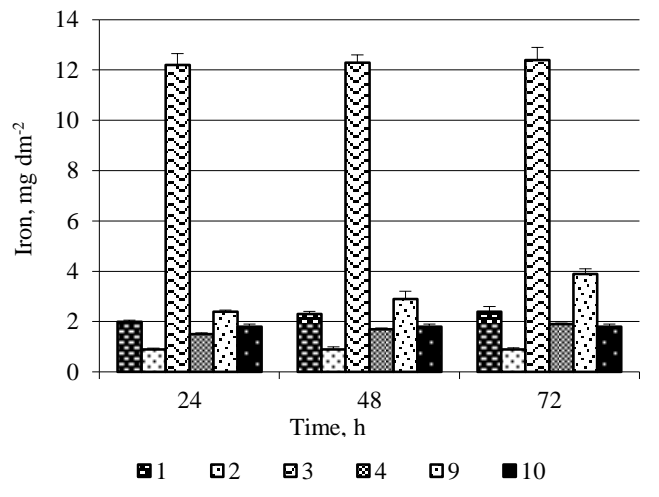

Figure 1. Migration of iron from glazed ceramic in $4 \%$ acetic acid at $20 \pm 2{ }^{\circ} \mathrm{C}$

Glazed stewing pottery (No. 1, No. 2, No. 3, No. 4 produced in Latvia; No. 9, No. 10 produced in China).

$*$ The results are presented as the mean $\pm \operatorname{SD}(n=3)$.

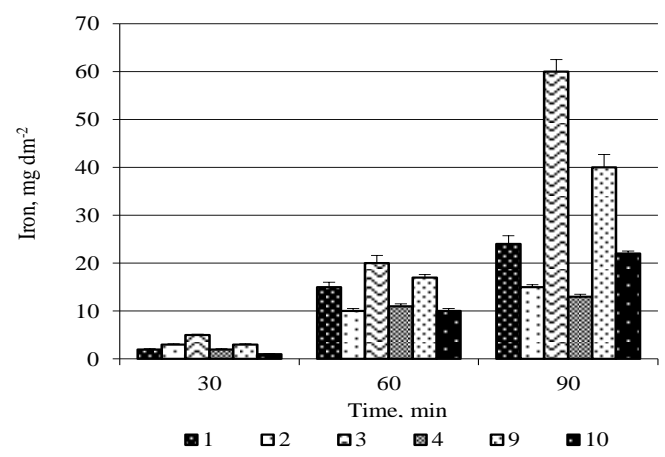

Figure 2. Migration of iron from glazed ceramic in $4 \%$ acetic acid at $180 \pm 5^{\circ} \mathrm{C}$

*Glazed stewing pottery (No. 1, No. 2, No. 3, No. 4; produced in Latvia; No. 9, No. 10; produced in China).

**The results are presented as the mean $\pm \operatorname{SD}(n=3)$.

Migration of iron from unglazed ceramic

Figure 4 shows the migration of iron at $20 \pm 2{ }^{\circ} \mathrm{C}$ from unglazed ceramic. Sample No. 5 had significantly lower migration of iron compared to other samples tested. In general, migration rate of iron from unglazed potteries was higher than that from glazed ware indicating that glazing could offer more protection against migration of clay components into food.

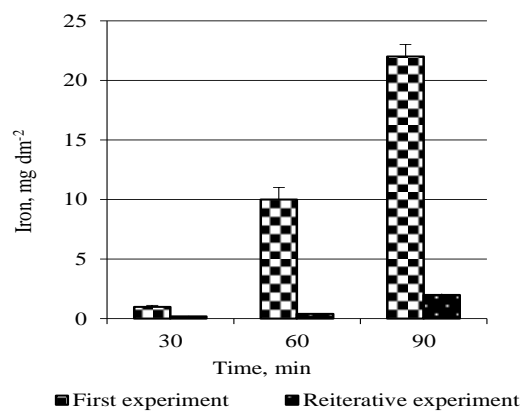

Figure 3. Migration of iron from glazed stewing potteries No. 10 in first treatment and reiterative experiment at $180 \pm 5^{\circ} \mathrm{C}$.

$*$ The results are presented as the mean $\pm \operatorname{SD}(n=3)$. 


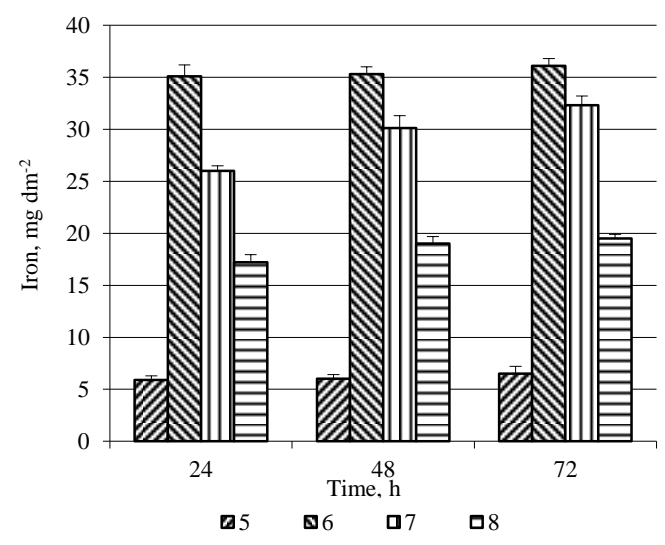

Figure 4. Migration of iron from unglazed ceramic in $4 \%$ acetic acid at $20 \pm 2{ }^{\circ} \mathrm{C}$

*Unglazed stewing pottery (No. 5, No. 6, No. 7, No. 8 produced in Latvia).

$* *$ The results are presented as the mean $\pm \mathrm{SD}(\mathrm{n}=3)$.

Similar to migration observations with glazed ceramic, migration of iron at $180 \pm 5{ }^{\circ} \mathrm{C}$ from unglazed clay was markedly facilitated in all the samples (Figure 5) as migration just after 60 minutes was higher than migration at $20 \pm 2{ }^{\circ} \mathrm{C}$ for $24-72 \mathrm{~h}$ (Figure 4).

Migration of aluminium from glazed and unglazed ceramic

Figure 6 shows the migration of aluminium at $20 \pm 2{ }^{\circ} \mathrm{C}$. Migration of aluminium was similar in all glazed ceramic samples and increased over time. In unglazed ceramic migration of aluminium was slightly higher than in glazed ceramic, but in general, this difference was not as marked as in case of migration of iron. Increase in temperature to $180 \pm 5^{\circ} \mathrm{C}$ markedly facilitated migration of aluminium in all the samples (Figure 7) and overall tendency was similar to migration at $20 \pm 2{ }^{\circ} \mathrm{C}$.

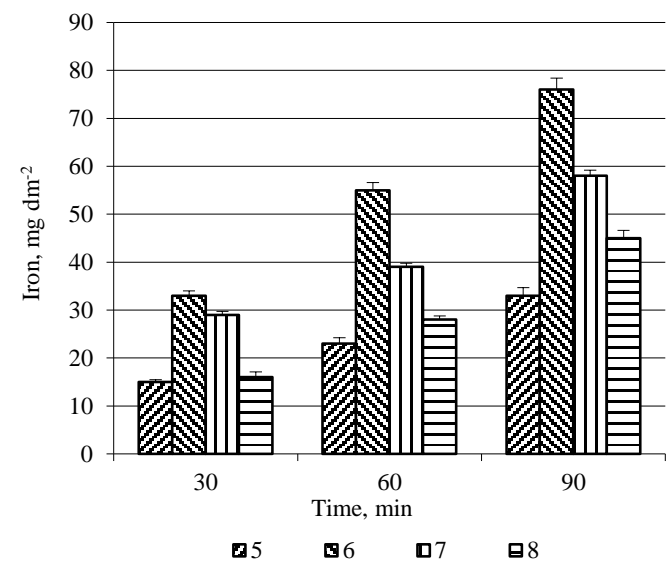

Figure 5. Migration of iron from unglazed ceramic in $4 \%$ acetic acid at $180 \pm 2{ }^{\circ} \mathrm{C}$

*Unglazed stewing pottery (No. 5, No. 6, No. 7, No. 8 produced in Latvia).

**The results are presented as the mean $\pm \mathrm{SD}(\mathrm{n}=3)$.

It is also clear that the migration of aluminium from the potteries was relatively high in either case. Clay compounds iron, silicon, magnesium and calcium are non-toxic elements. Migrations limits for aluminium have not yet been set in EU legislation.

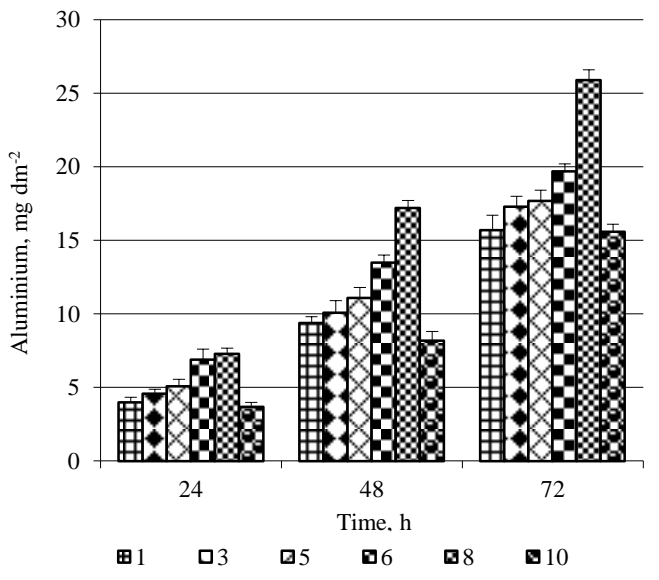

Figure 6. Migration of aluminium from glazed and unglazed ceramic in $4 \%$ acetic acid at $20 \pm 2{ }^{\circ} \mathrm{C}$

*Stewing pottery (glazed: No. 1, No. 3 produced in Latvia; No. 10 produced in China; unglazed: No. 5, No. 6, No. 8; produced in Latvia).

**The results are presented as the mean $\pm S D(n=3)$.

Biologically active aluminium is present in the human body and sometimes can be acutely toxic. Although not clearly proven yet, there are indications that chronic aluminium intoxication may be related to Alzheimer's disease, breast cancer and autism (Exley, 2016). Comparing maximal allowed concentration of aluminium in drinking water $\left(0.2 \mathrm{mg} \mathrm{L}^{-1}\right)$ (Regulation of the Cabinet of Ministers No. 235., 2003) and highest concentration of $37.8 \mathrm{mg} \mathrm{L}^{-1}$ of aluminium found in food simulant in this study (sample No. 8, after 90 min at $180 \pm 5^{\circ} \mathrm{C}$ ), it would be advisable to find means to limit migration of aluminium from clay potteries or limit the use of clay ceramics, particularly, unglazed ware at high temperatures. Pre-heating clay potteries filled with acidified water 1-2 times before actual use could be a relatively easy option to decrease aluminium migration in food.

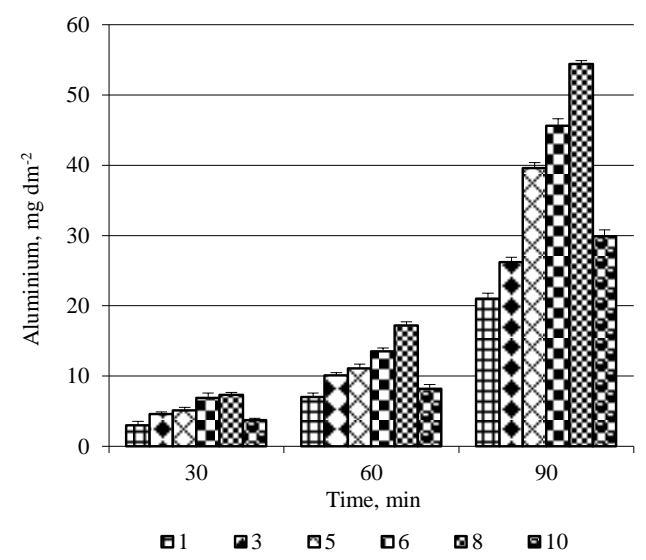

Figure 7. Migration of aluminium from glazed and unglazed ceramic in $4 \%$ acetic acid at $180 \pm 5^{\circ} \mathrm{C}$

*Stewing pottery (glazed: No. 1 , No. 3 produced in Latvia; No. 10 produced in China; unglazed: No. 5 , No. 6 , No. 8 produced in Latvia).

**The results are presented as the mean $\pm \mathrm{SD}(\mathrm{n}=3)$. 
Migration of silicon from glazed and unglazed ceramic One of main components of clay is $\mathrm{SiO}_{2}$ (Sedmanis et al., 2002) and it also can migrate. Although silicon was identified in all samples, the variations in migration among different potteries were very high. The content of clay varies a lot and this could explain high variability in migration of silicon (Figure 8).

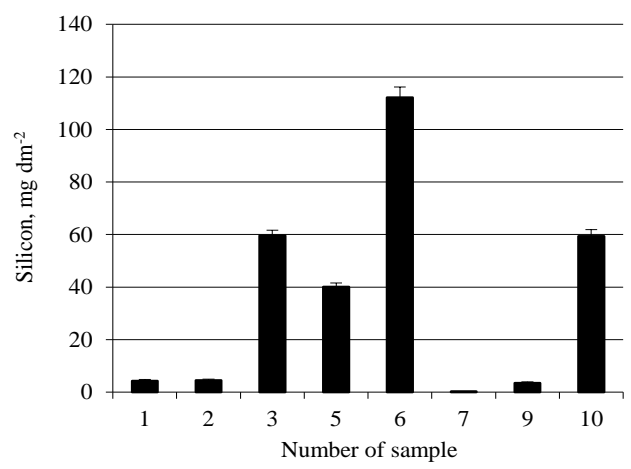

Figure 8. Migration of silicon from glazed and unglazed ceramic in $4 \%$ acetic acid at $20 \pm 2{ }^{\circ} \mathrm{C}$

*Stewing pottery (glazed: No. 1, No 2, No. 3 produced in Latvia; No. 9, No. 10 produced in China; unglazed: No. 5, No. 6, No. 7, No. 8 produced in Latvia).

**The results are presented as the mean $\pm \operatorname{SD}(n=3)$.

Migration of calcium and magnesium (sum) from glazed and unglazed ceramic

Figure 9 shows migration of calcium and magnesium (sum after $90 \mathrm{~min}$ at $180 \pm 5^{\circ} \mathrm{C}$ ). The migration rate of calcium and magnesium from potteries was highly variable, but in general migration was higher from unglazed ware.

Overall, clay potteries are not inert and various elements, particularly iron, aluminium, calcium and magnesium do migrate into acidic food simulants.

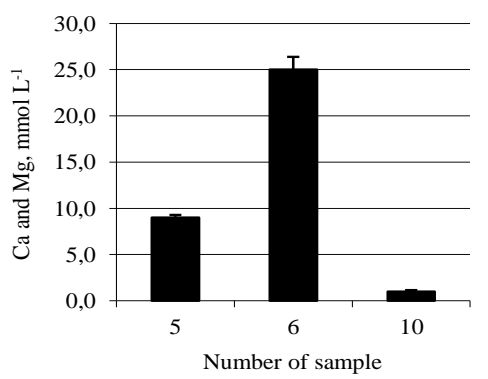

Figure 9. Migration of calcium and magnesium from glazed and unglazed ceramic in $4 \%$ acetic acid at $180 \pm 5^{\circ} \mathrm{C}$ after $90 \mathrm{~min}$

*Stewing pottery (glazed: No. 10 produced in China; unglazed: No. 5, No. 6 produced in Latvia).

**The results are presented as the mean $\pm \mathrm{SD}(\mathrm{n}=3)$.

Migration is markedly accelerated by increasing temperature, while glazing partially delays migration of elements. Of particular interest due to possible health related adverse effects might be migration of aluminium and it could be reasonable to test aluminium migration from clay potteries available on market.

\section{Conclusions}

The present study indicates that potteries are not inert ware and can readily interact with food-mimicking acetic acid solution in water, thus, it can be concluded that in a similar manner potteries could interact with real food. Migration rate of studied elements into the food simulant increased with the temperature and initially over time, but was significantly lower in repeatedly used ceramics. The migration rates of iron, aluminium, silicon, magnesium and calcium varied among different ceramics, but in general rates were higher in unglazed ware.

\section{References}

1. Bolle F., Fekete V., Demont M., Boutakhrit K., Petit D., Brian W., Feraille G., Loco J. (2012) Lead migration from ceramicware in contact with foodstuff: effect of glaze, temperature, $\mathrm{pH}$ and food simulant. Journal of Food Science and Engineering, Vol. 2, p. 301-313.

2. Commission directive 2005/31/EC of 29 April 2005 amending Council Directive 84/500/EEC as regards a declaration of compliance and performance criteria of the analytical method for ceramic articles intended to come into contact with foodstuffs. (2005) Official Journal of the European Union, L 110/36. [accessed on 21.02.2017.]. Available: http://eur-lex.europa.eu/legalcontent/EN/TXT/PDF/?uri=CELEX:32005L0031\&from= EN

3. Demont M, Boutakhrit K, Fekete V, Bolle F, Van Loco J. (2012) Migration of 18 trace elements from ceramic food contact material: influence of pigment, $\mathrm{pH}$, nature of acid and temperature. Food Chemical Toxicology, Vol. 50, p. 734-743.

4. Dong Z., Lu L., Liu Z. (2015) Migration model of toxic metals from ceramic food contact materiāls into acid food. Packaging Technology and Science, Vol. 28 (6), p. 545-556.

5. Dong Z., Lu L., Liu Z., Tang Y., Wang J. (2014) Migration of toxic metals from ceramic food packaging materials into acid food simulants. Mathematical Problems in Engineering, Vol. 10, p. 1-7.

6. Exley C. (2016) The toxicity of aluminium in humāns. Morphologie, Vol. 100 (329), p. 51-55.

7. Lin Q., Chen Y., Song H., Wu H., Wangx X. (2014) Kinetic Migration of Chemical Elements from Ceramic Packaging into Simulated Foods and Mature Vinegar. Packaging technology and science, Vol. 27, p. 59-67.

8. Ministru kabineta noteikumi Nr.235. (2003) Dzeramā ūdens obligātās nekaitīguma un kvalitātes prasības, monitoringa un kontroles kārtība. [accessed on 11.01.2017.]. Available at: https:// likumi.lv/doc.php?id=75442

9. Pastare S., Gigele R., Vīksna A. (2007) Dzeramais ūdens. Rīga: LU Akadēmiskais apgāds. 200 lpp.

10. Sedmanis U., Šperberga I., Sedmane G. (2002) Latvijas minerālās izejvielas un to izmantošana. Rīga: RTU. 196 lpp.

11. Szynal T., Rebeniak M., Mania M. (2016) Migration studies of nickel and chromium from ceramic and glass tableware into food simulants. Roczniki Państwowego Zaktadu Higieny, Vol. 67 (3), p. 247-252 